\title{
Indicators of sustainable development
} performance: Case study of European Union countries

\author{
Svjetlana Janković Šoja \\ Faculty of Agriculture, University of Belgrade, Serbia \\ svjetlanajs@agrif.bg.ac.rs \\ Dana Bucalo Jelić \\ Faculty of Agriculture, University of Belgrade, Serbia \\ bucalo@agrif.bg.ac.rs
}

\begin{abstract}
A sustainable development strategy is an essential long-term strategy that aims to bring about a balance of three key policy factors: sustainable economic growth and economic and technological development, sustainable development of society based on social equality, and environmental protection with a rational use of natural resources. The sustainable development strategy is very complex and contains a large number of indicators, so one of the statistical methods that can be used for this complex problem is the I-distance method. It was created as a need to rank countries according to the level of socio-economic development and the problem was how to take advantage of all the indicators in order to calculate a synthetic indicator which would represent the rank. The I-distance method in this paper is used for the ranking of 18 countries of the European Union based on ten indicators that have been selected in accordance with the EU Sustainable Development Strategy. The used headline indicators come from the following areas: socio-economic development, sustainable consumption and production, social inclusion, demographic changes, public health, climate change and energy, sustainable transport, and global partnership. By analysing the initial set of indicators and their correlation coefficients with the found I-distance values, the following most important indicators were found: official development assistance as a share of the gross national income, employment rate of older workers, healthy life years and life expectancy at birth (males), energy consumption of transport relative to GDP etc. Countries that occupied the top three places were Sweden, Luxembourg, and Finland while Croatia, Poland, and Slovenia occupied the last three places.
\end{abstract}

Keywords: EU countries, I-distance method, ranking, sustainable development indicators.

JEL classification: C38, F69, 131.

DOI: 10.1515/crebss-2016-0009

Received: September 20, 2016

Accepted: December 10, 2016 


\section{Introduction}

The aim of the Sustainable Development Strategy is to lead into balance: sustainable economic growth and economic and technological development, sustainable development of a society based on social equality, environmental protection, and the rational use of natural resources, in the long term. Due to the pressure made by the ever-increasing population, in comparison with the limited natural resources and food supplies, these problems are significant issues both at the national and international level. For this reason the balance should be found and the two opposing sides, the irresistible progress and ever-decreasing natural resources should be reconciled. Therefore, it is necessary to continuously monitor indicators that enable observation of the situation in a country, considering the field of sustainable development.

The first significant step in terms of sustainable development was the United Nations Conference on Environment and Development, which took place in 1992 in Rio de Janeiro. The Commission on Sustainable Development (CSD) was founded in 1993 and its aim was to supervise the implementation of decisions taken (United Nations, Division for Sustainable Development, 1992). For that purpose, the first set included 134 CSD indicators. During this time, this first set of indicators was tested several times, reviewed and adapted to the Millennium Development Goals. Currently, the actual set of indicators includes the 96 CSD indicators, of which 50 belong to the basic set of indicators (United Nation, Department of Economic and Social Affairs, 2007).

The EU Sustainable Development Strategy (EU SDS) was launched by the European Council in 2001 and renewed in June 2006s. Of more than 130 indicators, ten have been identified as headline indicators. Table 1 demonstrates ten thematic areas covered by the EU Sustainable Development Indicators (SDI) set. In addition, it could be seen how these themes are organised according to five dimensions of the EU SDS.

Table 1 The headline sustainable development indicators by Eurostat

\begin{tabular}{|c|c|c|}
\hline Dimension & Theme & Headline indicators \\
\hline \multirow{2}{*}{$\begin{array}{l}\text { Economic } \\
\text { development }\end{array}$} & $\begin{array}{l}\text { Socio-economic } \\
\text { development }\end{array}$ & Real GDP per capita, growth rate \\
\hline & $\begin{array}{l}\text { Sustainable consumption } \\
\text { and production }\end{array}$ & Resource productivity \\
\hline \multirow{3}{*}{$\begin{array}{l}\text { Social } \\
\text { development }\end{array}$} & Social inclusion & People at risk of poverty or social exclusion \\
\hline & Demographic changes & Employment rate of older workers \\
\hline & Public health & $\begin{array}{l}\text { Healthy life years and life expectancy at } \\
\text { birth, by sex }\end{array}$ \\
\hline \multirow{3}{*}{$\begin{array}{l}\text { Environmental } \\
\text { development }\end{array}$} & $\begin{array}{l}\text { Climate change and } \\
\text { energy }\end{array}$ & $\begin{array}{l}\text { Greenhouse gas emissions } \\
\text { Primary energy consumption }\end{array}$ \\
\hline & Sustainable transport & $\begin{array}{l}\text { Energy consumption of transport relative } \\
\text { to GDP }\end{array}$ \\
\hline & Natural resources & Common bird index \\
\hline $\begin{array}{l}\text { Global } \\
\text { partnership }\end{array}$ & Global partnership & $\begin{array}{l}\text { Official development assistance as share } \\
\text { of gross national income }\end{array}$ \\
\hline $\begin{array}{l}\text { Good } \\
\text { governance }\end{array}$ & Good governance & No headline indicator \\
\hline
\end{tabular}

Source: Eurostat, 2015. 
Due to the availability of data in this study, eight themes of EU Sustainable Development Strategy and eighteen EU countries are included. The theme "good governance' has no headline indicator because no indicator is considered sufficiently robust and policy-relevant to provide a comprehensive overview of the good governance concept (Eurostat, 2015). Dimension Environmental development consists of three themes: climate change and energy, sustainable transport and natural resources. Data for the headline indicator of theme natural resources "common bird index" are not available for many EU countries; hence, it is not taken into consideration in this research.

Therefore, in this paper the headline SDI of EU SDS was observed from the following areas: socio-economic development, sustainable consumption and production, social inclusion, demographic changes, public health, climate change and energy, sustainable transport, global partnership.

The aim of this research is to use the appropriate statistical procedures for ranking eighteen EU countries according to the level of Sustainable Development Strategy objectives achievements and thus, to identify EU countries which are lagging behind in this regard. Due to involvement of a large number of indicators in this research and due to the complexity of the problem, the statistical I-distance method has been chosen. This method was created as a tool to rank countries according to the level of socio-economic development and the problem was how to take advantage of all the indicators to calculate a synthetic indicator, which would represent the rank. This method is primarily applied for ranking countries conforming to their economic development level based on far fewer indicators (Ivanović, 1973; Ivanović, Fanchette, 1973) than are used today. Explanation is quite simple, modern computer technologies and adequate statistical packages provide solutions for highly dimensional input data matrix.

The idea for this research arose from research conducted by Janković Šoja et al. (2016) and Išljamović et al. (2015). The authors of study by Janković Šoja et al. (2016) included $28 \mathrm{EU}$ countries and ranked them according to the achieved objectives of the 2013 sustainable development strategy on the basis of 20 CSD indicators by UN. In other research by Isljamović et al. (2015), the authors analyzed the strategy of sustainable development of EU countries. The analysis includes a set of indicators that is formed on the basis of the experiences and research of the authors in the field of sustainable development. Group of authors Radojičić et al. (2012) also observed the issue of sustainable development in the EU countries, but with a set of headline indicators from the Eurostat during the year of 2010. Our intention is to establish whether there has been a shift in the ranking of some countries in the last five years.

\section{Literature review}

Numerous studies have recently dealt with the socio-economic development of the European Union countries (Radojičić et al., 2012; Išljamović et al., 2015; Janković Šoja et al., 2016) or MENA countries (Milenkovic et al., 2014) using the l-distance method. Furthermore, the I-distance method was used to rank the EU countries (EU-27) in accordance with the status of their healthcare systems (Jeremić et al., 2011a), as well as the world's universities (Jeremić et al., $2011 \mathrm{~b}$ ). The I-distance method was used in agro-economics studies for ranking the municipalities of the Republic of Serbia according to the level of small and medium entrepreneurship development in agribusiness (Popović, Maletić, 2008), or for ranking the municipalities of Vojvodina according to their business efficiency (Maletić, Popović, 2014), but also for ranking of the districts of the Republic of Serbia (Maletić, Popović, 2013) in line with the same criteria. 
In the research conducted by Janković Šoja et al. (2016), the indicators that measure sustainable development are chosen according to the instructions of the Commission on Sustainable Development (CSD), and are prepared by the United Nations Department of Economic and Social Affairs. CSD indicators are divided according to their themes which covers three major problems of sustainable development.

In research conducted by Išljamović et al. (2015), the input data for ranking 25 EU countries was obtained from the Eurostat, world development indicators from the World Bank, Yale's environmental performance index, ICT development index, Global Footprint Network and Economist Intelligence Unit for the period from 2007 to 2012. The selected indicators authors are classified into three thematic groups: economic indicators, social indicators and environmental indicators.

Considering the mentioned literature reviewed, the advantages of statistical Idistance method can be noticed. Firstly, it brings out the significant indicators, and then it ranks them according to the quantity and importance of the information for the specific research. Subsequently, it converts them into a single measure that reflects the level of the goals achieved.

\section{Methodology}

The indicators for measurement of sustainable development are chosen according to the EU Sustainable Development Strategy from Eurostat. The analysis included only the headline indicators from the areas of sustainable development in accordance with how are they divided to Eurostat (Table 2).

Table 2 The headline sustainable development indicators for measurement country's welfare

\begin{tabular}{|l|l|}
\multicolumn{1}{|c|}{$\begin{array}{c}\text { Areas of sustainable } \\
\text { development }\end{array}$} & \multicolumn{1}{c|}{ Headline indicators } \\
\hline Socio-economic development & Real GDP per capita, growth rate \\
\hline $\begin{array}{l}\text { Sustainable consumption and } \\
\text { production }\end{array}$ & Resource productivity \\
\hline Social inclusion & People at risk of poverty or social exclusion \\
\hline Demographic changes & Employment rate of older workers \\
\hline Public health & $\begin{array}{l}\text { Healthy life years and life expectancy at birth, females } \\
\text { Healthy life years and life expectancy at birth, males }\end{array}$ \\
\hline Climate change and energy & $\begin{array}{l}\text { Greenhouse gas emissions } \\
\text { Share of renewable energy in gross final energy } \\
\text { consumption }\end{array}$ \\
\hline Sustainable transport & Energy consumption of transport relative to GDP \\
\hline Global partnership & $\begin{array}{l}\text { Official development assistance as share of gross } \\
\text { national income }\end{array}$ \\
\hline
\end{tabular}

Source: Authors' own work.

Due to the availability of data on the observed indicators, the following eighteen EU countries are included in this study: Bulgaria, Greece, Croatia, Italy, Hungary, Austria, Romania, Slovenia, Czech Republic, Slovakia, Poland, Germany, Luxembourg, Spain, France, Portugal, Finland and Sweden. These countries are ranked in line with the achieved objectives of Sustainable Development Strategy under the three-year average value of the chosen indicators from 2012 until 2014.

The statistical l-distance method is applied to the selected indicators, which have been chosen to determine the concept of sustainable development. The statistical Idistance method is the metrics in an n-dimensional space, (Ivanović, 1963) which 
enables ranking of countries based on a larger number of indicators according to the development level in any field of economy and society. The advantage of this method is its ability to synthesize a large number of indicators into one numerical value, (Ivanović, 1963) which will further define the entity's rank.

For a selected set of variables $X^{T}=\left(X_{1}, X_{2}, \ldots, X_{k}\right)$ chosen to characterize the entities, the I-squared distance between the two entities $e_{r}=\left(x_{1 r}, x_{2 r}, \ldots, x_{k r}\right)$, and $e_{s}=\left(x_{1 s}, x_{2 s}, \ldots, x_{k s}\right)$ is defined as (Ivanović, 1977)

$$
D^{2}(r, s)=\sum_{i=1}^{k} \frac{d_{i}^{2}(r, s)}{\sigma_{i}^{2}} \prod_{j=1}^{i-1}\left(1-r_{j i .12 \ldots j-1}^{2}\right),
$$

where:

$$
d_{i}(r, s)=x_{i r}-x_{i}^{-}, i=1,2, \ldots, k,
$$

presents a discriminatory effect of the indicator $x_{i}$ of the observed country and the fictional unit $X_{i}^{-}$, which is, in this case, defined by the minimum values for each observed indicator, $\sigma_{i}$ is standard deviation of indicator $X_{i}$, and $r_{j i .12 \ldots . . j-1}$ is a partial coefficient of the correlation between indicators $X_{i}$ and $X_{j}$ (Ivanović, 1977). Due to the definition of a fictional unit, the country with the highest value of the I-squared distance achieved the best results in the implementation of the Sustainable Development Strategy. A fictional unit can also be defined with maximal and the average values of the indicators.

In practice, the I-squared distance is often used to avoid the negative partial coefficients of the correlation. The negative sign can be the result of the opposite direction of indicators (Jeremić et al., 2011c). Thus, in this paper, ranking was conducted by using the I-squared distance method.

The construction of the I-distance method has the following logic: the most significant indicator $\left(X_{1}\right)$ which is constructed to carry the most of the information for the specific research is being chosen and its discriminatory effect is computed; then, the next significant indicator $\left(X_{2}\right)$ whose discriminatory effect is not included in the previous indicator is involved in analysis. The analysis continues until all observed indicators are included.

\section{Results}

For the purpose of ranking the selected EU countries according to the level of achievement of the goals of Sustainable Development Strategy the I-squared distance method was applied to the indicators from Table 2. The obtained results were further revised by iterations. Each iteration indicates that we calculated coefficient of correlation between the obtained I-squared distance values and the values of the indicators. The procedure is repeated until the moment when the result can no longer be repaired. This procedure is elaborated in survey of authors Milenkovic et al. (2014). In this research, the best result and at the same time final one is obtained after four iterations. The explained procedure has singled out the most significant indicator, and the rest of indicators have been ranked due to their significance for actual research (Table 3).

Table 3 shows that the first six indicators are statistically significant $(p<0.05)$. The most significant indicator among them is Official development assistance as share of gross national income with $r=0.863(p<0.01)$. The same result was obtained in similar research of author Radojičić et al. (2012). Global partnership of the EU countries for obtaining the goals of sustainable development and welfare of countries is being 
highlighted in line with this result. In the same research the second position is taken by the indicator Healthy life years and life expectancy at birth, males, which represents public health, while in this research its positioned one ranking below $r=0.625(p<0.01)$. The second position was taken by indicator Employment rate of older workers with $r=0.751 \quad(p<0.01)$, which represents the area of sustainable development - demographic changes. In the majority of the papers in the field of socio-economic development and welfare of countries, GDP played an important role (Campisi et al., 2013; Espina, Arechavala, 2013; Mahdavi, Alanis, 2013; Markusen, 2013). However, in this research the role of indicator Real GDP per capita with $r=0.602(p<0.01)$ is slightly less significant and it takes the fifth position. The group of authors, Milenkovic et al. (2014), obtained the same result, that GDP or GNP per capita could not be the crucial indicator that describes a country's performance, since it cannot comprise overall country's welfare. On the other hand, an increase in the level of GDP per capita leads to an improvement of the population standard (Cracolici, Cuffaro, Nijkamp, 2010) and therefore the country can improve its position in the framework of the sustainable development strategy.

Table 3 Coefficient of correlation between the headline indicators and I-squared distance

\begin{tabular}{|l|c|}
\hline \multicolumn{1}{|c|}{ Headline indicators } & $\mathrm{R}$ \\
\hline Official development assistance as share of gross national income & $0.863^{* *}$ \\
Employment rate of older workers & $0.751^{* *}$ \\
Healthy life years and life expectancy at birth, males & $0.625^{* *}$ \\
Energy consumption of transport relative to GDP & $0.606^{* *}$ \\
Real GDP per capita, growth rate & $0.602^{* *}$ \\
Share of renewable energy in gross final energy consumption & $0.570^{*}$ \\
People at risk of poverty or social exclusion & 0.458 \\
Healthy life years and life expectancy at birth, females & 0.427 \\
Resource productivity & 0.373 \\
Greenhouse gas emissions & 0.197 \\
\hline
\end{tabular}

Note: ** $p<0.01 ;{ }^{*} p<0.05$.

Source: Authors' work.

Table 4 The results of the I-squared distance method for headline indicators

\begin{tabular}{|l|c|r|}
\hline \multicolumn{1}{|c|}{ Country } & I-squared distance & Rank \\
\hline Sweden & 52.79 & 1 \\
Luxembourg & 27.06 & 2 \\
Finland & 17.29 & 3 \\
Germany & 16.62 & 4 \\
Spain & 16.35 & 5 \\
France & 16.16 & 6 \\
Czech Republic & 14.73 & 7 \\
Greece & 13.84 & 8 \\
Portugal & 13.22 & 9 \\
Bulgaria & 12.23 & 10 \\
Austria & 10.73 & 11 \\
Italy & 9.86 & 12 \\
Romania & 9.35 & 13 \\
Slovakia & 6.39 & 14 \\
Hungary & 5.92 & 15 \\
Croatia & 5.24 & 16 \\
Poland & 4.25 & 17 \\
Slovenia & 4.10 & 18 \\
\hline
\end{tabular}

Source: Authors' work. 
According to the rank of indicators shown in Table 3, I-squared distance values have been calculated for each EU country and consequently ranking of 18 countries has been obtained. Results are shown in Table 4.

Table 4 shows that Sweden is on the top of the list according to the I-distance method. Radojičić et al. (2012) obtained the same result in research of the sustainable development of the EU countries. Luxembourg takes the second place, while in another similar study it takes the third place (Radojičić et al., 2012) and in another research it is in the first place (Išljamović et al., 2015; Koster, 2014). Koster (2014) observed the economic openness and welfare of 67 countries from different regions of the world and he pointed out that Luxemburg should be the role model. In this study, Luxemburg is followed by Finland, Germany, Spain, France etc. These results (Sweden on the first place and Finland on the third place) are not surprising because in recent years many studies have analysed the reasons for the welfare of the Scandinavian countries. The Scandinavian welfare model is based on direct and positive connection between the state and its citizens, universal social rights for all classes of society and relatively small differences between social classes (Alestalo, Hort, Kuhnle, 2009). The countries that have recently joined the European Union such as Romania, Slovakia, Hungary, Croatia, Poland, and Slovenia are at the bottom of the rank list. The same result is obtained in the paper of Išljamović et al. (2015) and Radojičić et al. (2012).

\section{Conclusions}

The main advantage of the I-distance method is that it enables ranking of the observed units based on a large number of indicators whose values are given per unit. Furthermore, it allows determination of the volume of information that each indicator provides, in order to set the position of a certain unit, in comparison with another unit. The I-distance method has wide practical usage and has proved to be accurate in ranking of observed units, which was shown in the research conducted by Jeremić et al. (2011b), for the ranking of the world's universities or by Maričic et al. (2016), for the analysis of the Quacquarelli Symonds World University Rankings by Subject in the field of statistics and operational research.

The I-distance method has primarily singled out indicators that significantly determine the level of achievement of sustainable development goals according to the amount of information they have for a specific study. Then this method ranks indicators based on their importance. The Official development assistance as share of gross national income stands out as the most significant indicator. This result emphasized the importance of global partnership of the EU countries to achieve sustainable development goals.

The I-distance method has pointed out that the EU countries, such as Sweden and Luxemburg, which took the first and second place, followed by Finland, Germany, Spain, France, have achieved better results in implementation of the sustainable development strategy and thus achieved good outcome. Moreover, they have distinguished from the countries that have lower level of the sustainable development goals achieved. Therefore, they are at the bottom of the ranking. Those are mainly the countries that have recently joined the European Union, as Romania, Slovakia, Hungary, Croatia, Poland and Slovenia. 


\section{References}

1. Alestalo, M., Hort, S. E. O., Kuhnle, S. (2009). The Nordic Model: Conditions, Origins, Outcomes, Lessons. Available at https://www.hertieschool.org/fileadmin/images/Downloads/working_papers/41.pdf [25 February 2016].

2. Campisi, D., de Nicola, A., Farhadi, M., Mancuso, P. (2013). Discovering the impact of ICT, FDI and human capital on GDP: a cross-sectional analysis. International Journal of Engineering Business Management, Vol. 5, No. 46, pp. 1-10.

3. Cracolici, M. F., Cuffaro, M., Nijkamp, P. (2010). The Measurement of Economic, Social and Environmental Performance of Countries: A Novel Approach. Social Indicators Research, Vol. 95, No. 2, pp. 339-356.

4. Espina, P. Z., Arechavala, N. S. (2013). An assessment of social welfare in Spain: territorial analysis using a synthetic welfare indicator. Social Indicators Research, Vol. 111, No. 1, pp. $1-23$.

5. Eurostat (2015). Sustainable development in the European Union, 2015 monitoring report of the EU Sustainable Development Strategy. Available at http://ec.europa.eu/eurostat/documents/3217494/6975281/KS-GT-15-001-EN-N.pdf [7. October 2016].

6. Išljamović, S., Jeremić, V., Petrović, N., Radojičić, Z. (2015). Colouring the socio-economic development into green: I-distance framework for counties' welfare evaluation. Quality and Quantity, Vol. 49, No. 2, pp. 617-629.

7. Ivanović, B. (1963). Discriminant analysis. Science books, Belgrade.

8. Ivanović, B. (1973). A Method of Establishing a List of Development Indicators. United Nations Educational, Scientific and Cultural Organization, Paris.

9. Ivanović, B. (1977). Classification Theory. Institute for Industrial Economic, Belgrade.

10.Ivanović, B., Fanchette, S. (1973). Grouping and Ranking of 30 Countries of Sub-Saharan Africa, Two Distance-based Methods Compared. United Nations Educational, Scientific and Cultural Organization, Paris.

11.Janković Šoja, S., Anokić, A., Bucalo Jelić, D., Maletić, R. (2016). Ranking EU Countries According to Their Level of Success in Achieving the Objectives of the Sustainable Development Strategy. Sustainability, Vol. 8, No. 4, pp. 1-10.

12.Jeremić, V., Bulajić, M., Martić, M., Radojičić, Z. (2011b). A fresh approach to evaluating the academic ranking of world universities. Scientometrics, Vol. 87, No. 3, pp. 587-596.

13.Jeremić, V., Išljamović, S., Petrovic, N., Radojičić, Z., Marković, A., Bulajić, M. (2011c). Human development index and sustainability: What's the correlation?. Metalurgia international, Vol. 16, No. 7, pp. 63-67.

14.Jeremić, V., Seke, K., Radojičić, Z., Jeremić, D., Marković, A., Slović, D., Aleksić, A. (2011 la). Measuring health of countries: a novel approach. HealthMED, Vol. 5, No. 6, pp. 1762-1766.

15. Koster, F. (2014). Economic openness and welfare state attitudes: a multilevel study across 67 countries. International Journal of Social Welfare, Vol. 23, No. 2, pp. 128-138.

16.Mahdavi, S., Alanis, E. (2013). Public expenditures and the unemployment rate in the American states: panel evidence. Applied Economics, Vol. 45, No. 20, pp. 2926-2937.

17.Maletić R., Popović, B. (2013). A Ranking of Serbian Districts Based on the Efficiency of SMEs in Agribusiness. Proceedings of the "Agriculture and Rural Development - Challenges of Transition and Integration Processes", Belgrade, Serbia, 27 September 2013, Department of Agricultural Economics, Faculty of Agriculture, University of Belgrade, Belgrade, Serbia, pp. 151-163.

18.Maletić, R., Popović, B. (2014). Ranking of Vojvodina municipalities based on efficiency of SMEs in agribusiness. Agroekonomika, Vol. 43, No. 63-64, pp. 39-48.

19.Maričić, M., Bulajić, M., Radojičić, Z., Jeremić, V. (2016). Multivariate approach to imposing additional constraints on the Benefit-of-the-Doubt model: The case of QS World University Rankings by Subject. Croatian Review of Economic, Business and Social Statistics, Vol. 2, No.1, pp. 1-14.

20.Markusen, J. (2013). Putting per-capita income back into trade theory. Journal of International Economics, Vol. 90, No. 2, pp. 255-265. 
21.Milenkovic, N., Vukmirovic, J., Bulajic, M., Radojicic, Z. (2014). A multivariate approach in measuring socio-economic development of MENA countries. Economic Modelling, Vol. 38, pp. 604-608.

22.Popović B., Maletić R. (2008). Grouping of municipalities of the Republic of Serbia based on development of small and medium agribusiness. Economics of Agriculture, Vol. 55, No. 2, pp. 151-161.

23.Radojičić, Z., Išljamović, S., Petrović, N., Jeremić, V. (2012). A novel approach to evaluating sustainable development. Problemy Ekorozwoju-Problems of Sustainable Development, Vol. 7, No. 1, pp. 81-85.

24.United Nation, Department of Economic and Social Affairs (2007). Indicators of Sustainable Development: Guidelines and Methodologies. Available at http://www.un.org/esa/sustdev/natlinfo/indicators/guidelines.pdf [01 December 2015].

25. United Nations, Division for Sustainable Development (1992). Agenda 21 . Available at https://sustainabledevelopment.un.org/content/documents/Agenda21.pdf

December 2015].

\section{About the authors}

Svjetlana Janković Šoja is a PhD Assistant Professor at the Department of Statistics at the Faculty of Agriculture, University of Belgrade. She graduated from Faculty of Economics, University of Belgrade in 2003 in the field of statistics and informatics. She received her PhD in 2016 at the Faculty of Organizational Sciences, University of Belgrade in the field of computational statistics. She is a member of the Statistical Society of Serbia. She can be contacted at svjetlanajs@agrif.bg.ac.rs

Dana Bucalo Jelić is the assistant at the Department of Statistics at the Faculty of Agriculture, University of Belgrade. She graduated in probability and mathematical statistics at the Faculty of Mathematics, University of Belgrade. Currently, she is doing her PhD studies at the Faculty of Mathematics, University of Belgrade. She can be contacted at bucalo@agrif.bg.ac.rs 